\title{
Examination of the Nexus Between Academic Libraries and Accreditation: Lessons from Nigeria
}

\section{Christopher Nkiko, Promise Ilo, Jerome Idiegbeyan-Ose \& Chidi Segun-} Adeniran

To cite this article: Christopher Nkiko, Promise Ilo, Jerome Idiegbeyan-Ose \& Chidi SegunAdeniran (2015) Examination of the Nexus Between Academic Libraries and Accreditation: Lessons from Nigeria, New Review of Academic Librarianship, 21:3, 325-338, DOI: 10.1080/13614533.2015.1036300

To link to this article: http://dx.doi.org/10.1080/13614533.2015.1036300

Accepted author version posted online: 08

Apr 2015.

Published online: 08 Apr 2015.

Submit your article to this journal $\pi$

Џ Article views: 42

View related articles $\smile$

View Crossmark data $\nearrow$ 


\title{
Examination of the Nexus Between Academic Libraries and Accreditation: Lessons from Nigeria
}

\author{
CHRISTOPHER NKIKO, PROMISE ILO, JEROME IDIEGBEYAN-OSE, \\ and CHIDI SEGUN-ADENIRAN \\ Centre for Learning Resources, Covenant University, Ota, Ogun State, Nigeria
}

\begin{abstract}
The article investigated the nexus between academic libraries and accreditation in the higher institutions with special focus on the Nigerian experience. It showed that all accreditation agencies place a bigh premium on library provisions as a major component of requisite benchmarks in determining the status of the program or institutions being assessed. Academic libraries belp to enrich formal classroom curricular and act as a broadening influence on lecturers and students as well as nurture in them the virtue of independent inquiry. State-of-the-art academic libraries confer prestige on the institutions and have tremendous impact on student retention, rankings, and bigh profiling of parent institution during accreditation. The article noted that there exists strong intrinsic and sometimes imperceptible relationship between academic libraries and higher education. It recommended institutionalization of global and regional ranking of academic libraries, among others.
\end{abstract}

KEYWORDS academic libraries, accreditation, library contributions and value, Nigerian accreditation

\section{INTRODUCTION}

The quality of teaching, learning, research, and general scholarship in any higher or tertiary education is proportionately related to the quality of its academic library. It is against this incontrovertible perspective that all ac-

(C) Christopher Nkiko, Promise Ilo, Jerome Idiegbeyan-Ose, and Chidi Segun-Adeniran

Address correspondence to Jerome Idiegbeyan-ose, Centre for Learning Resources, Covenant University, Ota, Ogun State, Nigeria. E-mail: jerome.idiegbeyanose@ covenantuniversity.edu.ng 
crediting agencies place a high premium on library provisions and services in determining the accreditation status of respective programs and institutions. The whole philosophy behind accreditation is premised on the need for functional quality assurance mechanism that guarantees internal and external institutional efficiency capable of producing outstanding graduates, first rate human capital, innovation, and perpetuation of best practices that situates higher education as an indispensable driver of human transformation, national development, and societal progress. The need to measure the contributions of the academic library to the overall goals of its parent institution, as well as evaluate the value of the library into such processes as academic accreditation have been noted by several studies (Pritchard 1996; Nkiko and Yusuf 2007; Lindauer 2014).

In Nigeria, the National Universities Commission is principally responsible for the accreditation of programs and institutions at the university level. Additionally, there are other professional accreditation bodies such as the Medical and Dental Council of Nigeria, the Council of Legal Education, Nigeria Institute of Architecture, Council of Registered Builders of Nigeria (CORBON), Council of Registered Engineers of Nigeria (COREN), Institute of Chartered Accountant of Nigeria (ICAN), and Librarians' Registration Council of Nigeria (LRCN). These professional bodies engage in rigorous quality assurance exercises to ascertain that graduates of the specific disciplines are integrated into the mainstream of professional best practices (Nkiko and Yusuf 2007).

It is worthy to note and trite to recognize that the several parameters that constitute the checklist of diverse accreditations in Nigeria include governance structure, staff ratio and mix, philosophy, vision and mission statements, library facilities, curriculum, funding, physical facilities, student support services, employers rating of alumni, and so forth. Each of these criteria is usually assigned various values that are meticulously adhered to. National Universities Commission (2014) observed that accreditation status of an academic program may be identified at one of the following three levels:

i. Full Accreditation: this is usually granted to any other academic program that has satisfied the provisions of Minimum Academic Standards (MAS). Full accreditation is granted for a period of six (6) academic sessions with a mid-term appraisal after three (3) years. After the six academic sessions, there is normally a re-accreditation visit.

ii. Interim Accreditation: this is granted to any academic program that has minor deficiencies that must be rectified within a stipulated period. It is granted for a period not more than two (2) academic sessions after which the program is automatically due for re-visitation.

iii. Denied Accreditation: this applies to any program that has failed to satisfy the approved Minimum Academic Standard (MAS). Request for 
re-visitation for the purpose of accreditation must come from the university concerned.

It would be appropriate to stress the implication of denied accreditation at this point. When an academic program has been denied accreditation status, the NUC informs the Vice-Chancellor of the university concerned in writing stating the reasons for such and prescribed steps to remedy the situation. Thereafter, the university is prohibited from admitting students into such program with effect from the next admission exercise. The proprietors are also advised to stop funding the program. Suffice it also to mention that the general public and relevant bodies such as the Joint Admissions and Matriculation Board (JAMB), the National youth Service Corps (NYSC), the Civil Service Commission, and other employers as well as Scholarship Boards are usually notified.

The centrality of library provisions in the exercises is underscored by the fact that no program scoring less than seventy percent in this criterion can earn full accreditation. Noting the omnibus and pervasiveness of academic libraries in accreditations, the article explored the nexus between libraries and its contributions to the overall rating of the parent institutions in peer review mechanisms.

\section{ACADEMIC LIBRARIES IN NIGERIA}

It is pertinent to note here that one of the paramount reasons for the establishment of higher institutions in the country is to encourage and promote research, learning, and scholarship via knowledge transfer and development of appropriate competencies (Eze and Uzoigwe 2013). The library in any higher institution of learning is in the lifeblood of that institution. In the same vein, Yusuf and Iwu (2010) noted that "the academic library is the nerve centre or the hub around which scholarship revolves" (1). It is also an instrument for intellectual development. Kaufman (2005) reiterated that the academic library is often referred to as the "jewel" in the institution's crown, the heart of the institution, and the campus' treasure. This shows how instrumental the library is in the attainment of the objectives of the higher institution. The indispensability and intertwined nature of academic libraries to education is as depicted in Figure 1.

Higher institutions' goal is to promote research and learning and the academic library is at the core of this objective, because it is the knowledge and information hub of any higher institution.

Aina (2004) avers that academic libraries are those libraries attached to post-secondary institutions whose functions are directly related to the mission of their parent body, which in most instances center on learning, research, and teaching. 


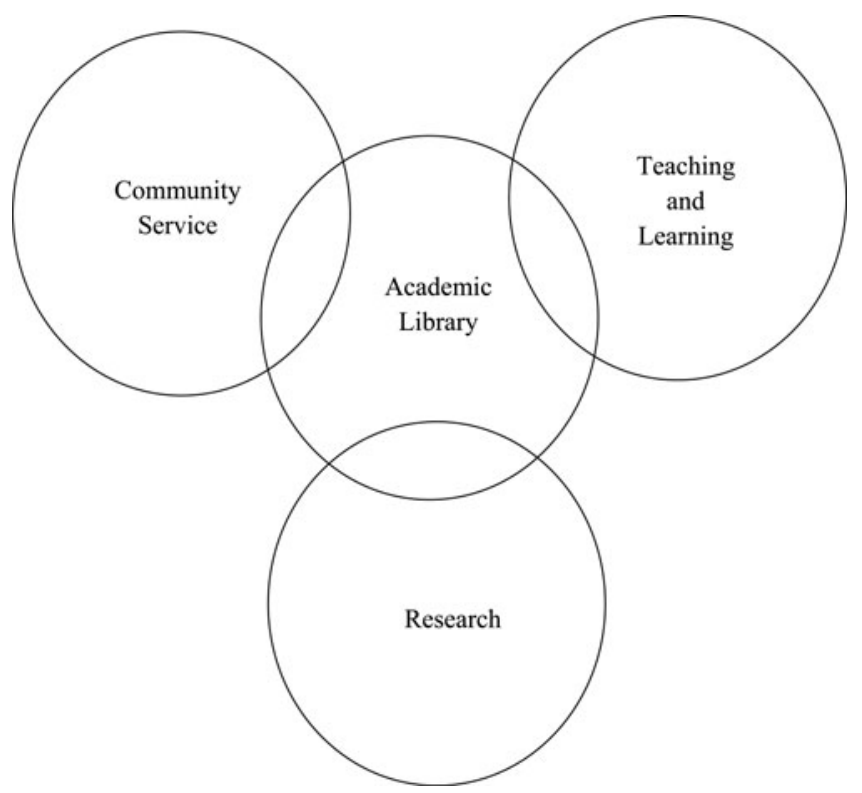

FIGURE 1 Model showing Academic Library as the life wire of any institution of Higher Learning. Source: Originally developed for this study.

The academic library is therefore a subsystem of the main parent organization, decked with the responsibility of providing services for studies and research. It is an important unit of any organization or institution's information infrastructure and an active participant in the learning process usually characterized by the abundance of information resources (Juceviciene and Tautkeviciene 2003). Consequently, we can explain academic libraries as being set up primarily to see to the satisfaction of the academic, social, career, cultural, and religious needs of its varying categories of users both from within and outside its environment. They select, acquire, catalogue, classify, preserve, and disseminate information resources.

\section{FUNCTIONS OF ACADEMIC LIBRARIES}

The collections in the academic library especially in this digital age vary from print to electronic materials and they cover various disciplines and fields of learning. The availability of print and electronic resources together with the skilled information professionals help in achieving the objectives of the library toward satisfaction of the clients. Similarly, Isiakpona and Ifijeh (2012) explained that the library's driving philosophy is to provide the right information for the right patron at the right time. 
The functions of the academic library in any institution are broadly to support teaching, research and learning; Aina (2004) outlined the following specific functions of an academic library:

- Reading and lending services

- Reference services

- Virtual library service

- User education

- Selective Dissemination of Information

- Current Awareness Service

- Community Development Service

Beyond these major functions, the library usually engages in other ancillary services that vary depending on peculiarities of each parent institutions. Additionally, as a growing organism, new developments in technology and curricular emphasis may necessitate further interventions from thex library.

\section{ACCREDITATION}

Accreditation can be defined as a peer-review process that assures the quality of education that students received in terms of standard. The main propose of accreditation is for the improvement of the quality and standard of education. Accreditation has two fundamental purposes: to guarantee the quality of an institution or program and to assist in the improvement of the institution and its programs (Global Accreditation Centre for Project Management 2014). Accreditation involves a collective analysis and judgment by an institution's internal constituencies, an informed review by peers external to the institution, and a reasoned decision by the elected members of the Commission for Accreditation. The institution continuously conducts an internal review mechanism to determine the quality and standard of their functions and services. Accreditation is the brain behind the quality of education in any country (Commission on Colleges of the Southern Association of Colleges and Schools 2004).

Oladosu (2011) cited Hornb (2001) and defined accreditation as the official approval granted by an accreditation agency to an educational institution at the end of a successful assessment exercise. It is also the process or method that is carried out to access the standard and quality of an educational institution. The main thrust of an accreditation exercise is to improve the standard and quality of education, but its successful implementation depends on the quality and commitment of the accreditation bodies (Adeyemi and Adediran 2009; Oladosu 2011).

Jaiyeoba and Ademola (2014) reported that accreditation of university education began in Africa in 1985 in Kenya, followed by Nigeria in 1990, 
and Cameroon in 1991. In Nigeria, various accreditation bodies are set up by the government to monitor, enforce quality, and standard of education in the country. The National Universities Commission (NUC) is responsible for the accreditation of the nation's university; Oribabor (2008) noted that the NUC is responsible for the accreditation of the university programs in Nigeria and subsequent standardization of the programs. The National Board for Colleges of Education is responsible for colleges of education, whereas the National Board for Polytechnic is responsible for accreditation of the nations' polytechnics.

\section{Purpose of Accreditation in Nigerian Universities}

Nigeria presently has 129 universities. This includes forty federal, thirty-nine state, and fifty private universities (National Universities Commission 2014).

In actual fact, there is need for regulations and standardization of these university infrastructures and facilities. Accreditation of universities can as well serve as the monitoring force to improve the standard of education in the country. If there is no control and monitoring of the quality of resources in these universities, the standard of education will be nothing to write home about, as these accreditation bodies set out minimum standard and benchmark for all universities.

Actually in Nigeria and other countries of the world, parents and candidates seeking admission to higher institutions consider the accreditation status of the university and the programs before applying to the institutions.

Accreditation of universities is a basis for government and private funding of the institution and its programs. It raises public confidence in the authenticity of the value of the education offered. It remains the basis of recognition of degrees for academic and employment purposes. Koenig, Lofstad, and Staab (2004) stressed that accreditation assures the educational community, the general public, and other organizations and agencies that an accredited institution meets the commission's requirements to institutional capacity and educational effectiveness to standards. The goal of accreditation is to ensure that education provided to the citizens by institutions of higher learning meets acceptable levels of quality, standard, and minimum benchmark (Western Association of Schools and Colleges 2008; Elia and Moore 2008).

\section{Types of Accreditation in Nigerian Institutions of Higher Learning}

Basically there are two types of accreditation in Nigerian higher institutions. These are institutional accreditation and Program accreditation. Institutional accreditation has to do with accrediting the entire institution as a whole, 
whereas program accreditation covers the different programs run by the institution. Jaiyeoba and Ademola (2014) cited Hayward (2006) and reinforced that there are two forms of accreditation that include institutional and program accreditation. In any case, the library is crucial to the success or failure of both the institutional and program accreditations. The status of accreditation of any institution whether institutional or program has direct relationship with the state of the library and its resources.

In Nigeria, the status of accreditation is classified as full, interim, or denied. Full accreditation is earned when a program scores $70 \%$ and above in each of the core areas of staffing, academic content, physical facilities, and library. Interim accreditation is earned when the program score is between 40-69\% in all the core areas. Denied accreditation results from a score below $40 \%$ in all the core areas. The implication of denied accreditation is that the university will not admit students in that program until another accreditation is carried out and the program score meets the requirements (Ayodele and Awe 2007; Oladosu 2011; Abayomi and Olabanji 2013).

Contributions of Academic Libraries to Accreditation: The Nigeria experience

Accreditation helps foster a new sense of concern about improving teaching, learning, research, and public service in higher institutions, which in turn makes institutions and their graduates more competitive, effective, and able to make greater contributions to the national development (Jaiyeoba and Ademola 2014).

Academic libraries in Nigeria play strategic roles in their parent institution accreditation; whether institutional or program accreditation. Figure 2 provides a conceptual model of libraries' contribution to accreditation.

The Nigerian National Policy on Education Revised (Federal Republic of Nigeria 2004) stipulates that libraries must be established and well equipped as part of any educational institution in the country. Academic libraries are at the forefront of providing information services to their respective communities comprising students, lecturers, and researchers. Issah and Tunde (2013) quoting Abubakar (2011) avers that it is an indispensable instrument for intellectual development, being a store house of information to which users may turn to for accessing information.

The robustness of library provisions in an institution creates a most enabling learning platform for exploratory and independent intellectual enquiry. The library provides opportunity for reading a wide variety of books, viewing audio-visual resources, and teaching information search techniques. This support helps to enrich formal classroom curriculum and acts as a broadening influence on lecturers and students. It must be pointed out the best lecture notes do not contain encyclopedic information on any topic. The 


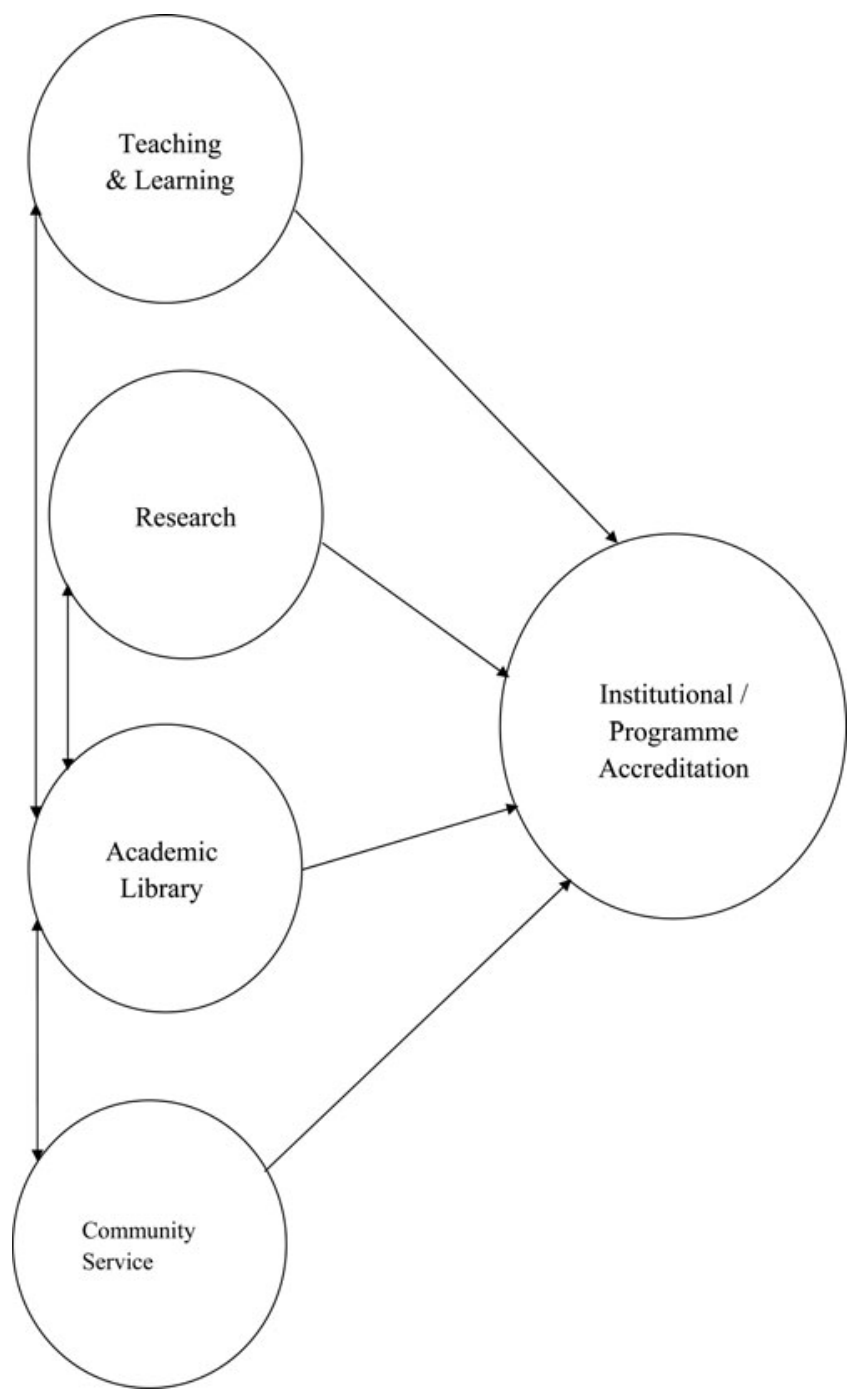

FIGURE 2 Conceptual model of the strategic role of academic library in accreditation. Source: Originally developed for this study.

library thus, provides a profitable platform through which students could explore, experiment, and discover facts for themselves. This helps to cultivate and nurture in them the virtue of independent inquiry which is the gateway to lasting knowledge. The students are therefore able to concretize, consolidate, and gain mastery over issues raised in class. Knowledge acquired through participatory and individual engagement tends to last longer than rote learning. The library interface promotes confidence and originality in the students culminating to astute and highly versatile undergraduates and graduates. It imbues in them the culture of critical reasoning. That is, the capacity 
to question existing knowledge or paradigms rooted in the belief that there are diverse perspectives and notions to any issue of intellectual discourse. These outcomes resonate with accreditation expectations and leads to high profiling of the institutions by the regulatory bodies.

The teaching quality and effectiveness of institutions with virile academic libraries experience outstanding boost. Contents to course modules and courseware are usually drawn from plethora of sources to form integrated and comprehensive lecture materials that make for easy and stimulating delivery. In the absence of such broad-based analogue and digital collections, the most dedicated lecturer would at best resort to residual knowledge and thus create unbridgeable lacuna or gap in the intellectual development of students.

Similarly, ground-breaking researches and procurement of external competitive research grants are traceable to the compelling library resources and services. In Covenant University, Nigeria librarians provide specialized dissemination of information to busy senior faculty based on their research and teaching interests and other community initiatives. This serves to provide relevant data and literature for writing sound grant proposals. There are liaison librarians assigned to various schools and research clusters, thus helping to optimize the utilization of avalanche of library resources with a resultant positive impact on academic productivity of the university faculty. Research activities would be drudgery and herculean in the absence of information and library resources.

The librarians use their professional expertise of classification, cataloguing, indexing, and abstracting to facilitate learning and research by empowering faculty and students to function self-sufficiently in their bid to forage myriads of information resources. Through both formal and informal bibliographic instructions, library users are equipped with requisite skills to locate and access key resources that enhance teaching, learning, and research.

The corollary of the foregoing is the truism that students with broadbased knowledge which the library provides have greater propensity to catalyze and facilitate quality teaching. Students who have been enmeshed into solid bibliographic instructions only come to the class to clarify and reinforce information already gleaned from diverse sources. They usually put the lecturers on their toes and thus invariably prevent poor and inadequate preparations on the part of the teachers. Symbiotically, the teachers learn and update their knowledge through new postulations from their students. This scenario is only possible through effective library support services, hence Simmons (1991) strongly held that "the development of information literate students and faculty is a shared responsibility of the librarian and the teacher, and that general education programmes are not entirely effective without library-based research" (393).

State-of-the-art academic libraries confer prestige on the parent institutions as they tacitly depict the core activities of the university as that of 
learning and research. Brown (2014) posited that outstanding libraries have a tremendous impact on student retention, teaching, and university rankings as well as accreditation. Accreditation agents are usually fascinated with the sight of great number of students in the library engrossed in studies during their visits. Impressive libraries hold special allure and attraction to students as well as reduces attrition rate based on dissatisfaction of support services. Even the institutional alumni connect back with nostalgia to the library's captivating environment, first rate and multi-faceted intellectual contents available in various formats. Libraries are instruments for curbing crimes and youthful restiveness as well as veritable facilities for improving skills and employability (Nkiko 2005; Azikiwe 2001). Good libraries, therefore, imperceptibly shape the character and world-view of members of the academic community thereby creating an ambience of inspiration, creativity, innovation, and discovery.

The Library inculcates in the users necessary information literacy skills that make for life-long learning. As a result of information explosion and rapid dynamism of knowledge, most things learned in the university expire within six months of graduation. Those who are not able to keep pace with latest developments sooner or later relapse into secondary illiteracy.

The continuous learning skills required to be current and abreast of innovation become imperative. The requisite abilities to interrogate all phenomena, deconstruct and reconstruct emerging realities with a view to distilling solutions to myriads of societal problems lie the whole essence of education. It is beyond certification but empowerment to continuous relevance through knowledge creation, dissemination, and utilization; thus, the library equips the graduates with life skills.

\section{LESSONS FROM NIGERIA}

The academic excellence recorded by Nigerian Universities in the seventies is traceable to huge and adequate funding of university libraries (Ifidon 2006). The scholars were adjudged as good or at times better than their foreign counterparts because they had access to well stocked libraries. The paucity of funding in academic libraries from the nineties has correlated to a nose dive in the general standard of higher education. It is important to note that consistent investment in world-class learning resources is the only way to sustain academic excellence and maintain global relevance in terms of scholarship and intellectual productivity.

It is in realization of the undeniable positive correlation between library content and quality of education that Covenant University, one of the top profiled private universities in Nigeria, invests massively and consistently in its library and information resources having one of the best academic libraries in Nigeria (Aina 2013). It is not surprising then that Covenant University 
emerged the best in two consecutive editions of the Presidential Special Scholarship Scheme for Innovation and Development (PRESSID), organized by the president of the Federal Republic of Nigeria to sponsor the one hundred first class graduates of Nigerian Universities to the top 25 worldclass universities. Consistently, Covenant University has produced about 10\% of the qualified candidates in the country (Okojie 2014).

Nkiko and Yusuf (2007), drawing from accreditation experiences in Nigeria, highlighted ethical considerations required to validate accreditation verdicts. Some of the ethical considerations include and not limited to:

- Honesty: the situation where institutions engage in massive window dressing to impress the accreditors is not only misleading but outright misrepresentation. This kind of dishonest practices range from hiring personnel on contract for accreditation purpose, borrowing books and other equipment and return as soon as the exercise is over, creating fictitious records, and files, and so forth. It is only when institutions are transparent that accreditation reports will reflect the true state of affairs.

- Integrity: visiting panel members must be above board in their dealings with the institutions. They must stick to principles even in the face of pressure. There is this belief that everybody has a price-tag and must be negotiated. It is really about preserving the future of higher education. The joy of advancing the education and development of posterity should be priced above personal gains and aggrandizement.

- Objectivity: panelists must conduct the review in a way that places them above prejudices, biases, self-interest, religious inclination, and ethnic preferences. Assessments have to be fair, transparent, and consistent with the checklist. Pre-conceived notions should be jettisoned while facts are celebrated, enthroned, and properly reported.

- Mutuality: any genuine and worthwhile accreditation seeks ways to make constructive contributions that advance the current practices in the department or program concerned. The university management must not be unnecessarily defensive but be willing to learn and benefit from the experience of external colleagues. This type of mutuality provides a most conducive atmosphere for effective accreditation.

\section{CONCLUSION AND RECOMMENDATIONS}

The article has demonstrated the intrinsic and sometimes imperceptible relationship between academic libraries and quality of higher education, noting that all accreditation agencies recognize this fact; hence, library resources form a vital component of accreditation benchmarks. Libraries have continually over the ages remained the hub of learning, teaching, and research in 
the university community. The case of Covenant University with outstanding academic library coming top position in two consecutive times in the Presidential Scholarship Competition for First Class graduates in the country is an eloquent corroboration of strong relationship between the library and academic productivity and institutional profiling.

Having established the intricate value of libraries to academic institutions, it is recommended that there should exist a body undertaking the global and regional ranking of academic libraries. Publication of ranking status of academic libraries would sensitize and propel the proprietors or parent institutions to greater funding. This would transcend the current practice of making libraries a component of accreditation parameters. International Federation of Library Associations (IFLA) and other regional library associations should develop uniform and standard checklist and parameters for measuring library equipment, resources, operations, and personnel. In the same way that the current ranking of universities has compelled the entrenchment of some quality imperatives, the special focus on academic libraries through this mechanism would further accentuate academic libraries as the lifeline of education:

a) To forestall and mitigate sharp practices where institutions take recourse to only equipping the libraries for accreditation purposes; and b) a window dressing syndrome that gives a false impression and detracts from the true benefit of library services. Libraries should be made to publish their holdings and other assets periodically. International regulatory authorities need to engage on the spot inspection and unannounced regular visits. In order to safeguard the sovereignty of countries, the UNESCO appears more suitable to undertake this task. Alternatively, respective countries should be approached to enter into multi-lateral agreements on promoting quality academic libraries.

Accreditations in the future are recommended to include the quality of organization of library resources in accordance with Resource Description and Access (RDA) framework and other standard metadata. This would involve a departure from the present system, whereby non-librarians who are oblivious of standard library practices provide verdicts on the state of the library during accreditations. There is a need for professionals' judgement in respect to specialized issues such as classification, cataloguing, indexing, abstracting, and so forth, as organization is the hallmark of librarianship.

\section{REFERENCES}

Abayomi, A. A., and E. O. Olabanji. "Accreditation and Quality Assurance in Nigerian Universities." Journal of Education ad Practice. 4.8 (2013): 34-41. Web. 10 Oct. 2014. <http://www.iiste.org>.

Adeyemi, B. A., and V. O. Adediran. "Issues and Trends in Nigerian Educational System." Principles and Practice of Education. Ed. O. J. Ehindero, F. O. Aladejana, 
and P. O. Jegede. Obafemi Awolowo University Press, 2009. Print. Aina, L.O. "Covenant University Library" The Punch Newspaper. 21 Jul. 2013: 67. Print.

- Library and Information Text for Africa. 27-31. Ile-Ife, Ibadan: Third World Information Service, 2004; 27-31. Print.

Ayodele, J. B., and B. Awe. "Quality Assurance: An Appraisal of Accreditation in Nigeria Universities." Access, Equity and Quality in Higher Education. Ed. J. B. Babalola, G. O. Akpan, A. O. Ayeni, and S. Adedeji. Ibadan: NAEP Publication, 2007. Print.

Azikiwe, N. My Odyssey: An Autobiography. Ibadan: Spectrum, 2001, 36. Print.

Brown, M. "Nigerian University Library: The Value of Academic and research libraries: A Conference of Knowledge." Paper presented at the Committee of University Librarians of Nigerian Universities, University Of Lagos, 7-11 April, 2014. 7-8. Print.

Commission on Colleges of the Southern Association of Colleges and Schools. 2004. Web. 25 Sept. 2014. <http://www.google.com>.

Elia, D. E., and J. Moore. "Why National Standard and Accreditation are needed for Baccalaureate Degree Programmes in Biology." 2008. Web. 30 Sept. 2014. <https://uk-mg42.mail.yahoo.com/neo/launch?.rand=09scrf35d01di\# $8411082564>$.

Eze, J. U., and C. U. Uzoigwe. "The Place of Academic Libraries in Nigerian University Education: Contributing to the 'Education for All' Initiative." Academic Journals 5.10 (2013): 432-38. Print.

Federal Republic of Nigeria. National Policy on Education. Lagos: NERDC, 2004. Print.

Global Accreditation Center for Project Management. Handbook of Accreditation on Degree Program on Project Management. 3rd Ed. 2014. Web. 25 Sept. 2014. $<$ http://www.google.com $>$.

Ifidon, S. E. Modern Theory and practice of Library Collection Development. Justice Jeco Press and Publishers. Benin: Nigeria, 2006, 66-67. Print.

Isiakpona, C., and G. Ifijeh. "Availability of Electronic Resources for Service Provision in University Libraries in Ogun State, Nigeria." Samaru Journal of Information Studies 12.1-2 (2012): 7-14. Print.

Issah, A., and O. K. Tunde. "The Quality of Nigerian Higher Education and the Funding of Library Resources." Ozean Journal of Social Sciences 6.2 (2013): 43-53. Web. 1 Oct. 2014. <http://ozelacademy.com/ojss.v6.i2-3.pdf>.

Jaiyeoba, A. O., and A. I. Ademola. "Re- Engineering Tertiary Education (University) for Sustainable Development in Nigeria.” 2014. Web. 2 Oct. 2014. http://webcache.googleusercontent.com/search?q=cache:InF8guHARikJ:herpnet.org/REFORMING_HIGHER_EDUCATION_IN_AFRICA/Chapter\%25204.pdf+ $\& \mathrm{~cd}=7 \& \mathrm{hl}=\mathrm{en} \& \mathrm{ct}=\mathrm{clnk} \& \mathrm{gl}=\mathrm{ng}>$.

Juceviciene, P., and G. Tautkeviciene. "Academic Library as a Learning Environment: How do Students Perceive It?" Paper Presented at the European Conference on Educational Research, University of Hamburg, 17-20 September, 2003. Print.

Kaufman, P. "Role and Mission of Academic Libraries: Present and Future." Japan Association of Private University Libraries Symposium, Kansai University, November 18, 2005. Print. 
Koenig, A. M., R. Lofstad, and E. Staab. "Higher Education Accreditation in the United States: What International Education Professionals Need to Know." Paper Presented at EAIE Conference, Torino 18 September, 2004. Print.

Lindauer, B. G. "Defining and Measuring the Library's Impact on Campus Wide Outcomes." Journal College \& Research Libraries 59.6 (2014): 546-70. Web. 31 Oct. 2014. <http:www.clr.acrl.org/content/59/6/546>.

National Universities Commission. 2014: List of Nigerian Universities and Years Founded. Web. 29 Sept. 2014. <http://www.nuc.edu.ng/pages/universities. asp $>$.

Nkiko, C. "Information Literacy in Educational and National Development: Libraries as an Anchor." Journal of Library and Information Science 2.1 (2005): 2-11. Print.

Nkiko, C., and F. Yusuf. "Accreditation Issues for Library and Information Science Schools." Journal of Applied Information Science and Technology 1.1 (2007): 70-82. Print.

Okojie, J. "PRESSID: Covenant University's First Class Graduates Top Again.” The Nation, 10 April, 2014: 6. Print.

Oladosu, A. G. A. S. "Accreditation in Nigeria Universities: The Role of the Academic Planners." Paper presented at a Training Workshop for Academic Planning Officers in Nigerian Universities, Organized by the Committee of Directors of Academic Planning of Nigerian Universities (CODAPNU) in Collaboration with the National Universities Commission (NUC), beld at NUC Auditorium, Abuja, 12-15 Jul. 2011. Print.

Oribabor, O. A. "Impact of National Universities Commission (NUC) Accreditation Exercise on University Administrative Structure." African Research Review: An International Multidisciplinary Journal, Ethiopia 2.3 (2008): 222-23. Web. 30 Sept. 2014. <http://www.google.com.ng/url?sa=t\&rct=j\&q=\&esrc=s\&source= web\&cd =9\&ved=0CE8QFjAI\&url=http $\% 3 \mathrm{~A} \% 2 \mathrm{~F} \% 2$ Fafrrevjo.net $\% 2$ Fjournals $\% 2$ Fmultidiscipline\%2FVol_2_num_3_art_15_Oribabor.pdf\&ei=bNUqVJbqDsKM7 Aa0toGIDw\&usg=AFQjCNGNLevu7VrcCMnjbpc0k9gmT7hhoA\&bvm=bv.7647 7589, d.ZGU>.

Pritchard, S. M. "Determining Quality in Academic Libraries." Library Trends 44.3 (1996): 572-94. Print.

Simmons, H. L. "Accreditation Expectations for Library Support of Off-Campus Programs." Library Trends 39.4 (1991): 388-404. Print.

Western Association of Schools and Colleges. "Handbook of Accreditation 2008." 2008. Alameda, CA: Western Association of Schools and Colleges. Web. 30 Sept. 2014. <http://www.google.com.ng/url?sa=t\&rct=j\&q $=\& e s r c=s \&$ source $=$ web $\& c d=8 \& v e d=0 \mathrm{CEkQFjAH} \& u r l=h t t p \% 3 \mathrm{~A} \% 2 \mathrm{~F} \% 2 \mathrm{Fwww}$. w-ascsenior.org\%2Ffiles\%2FHandbook_of_Accreditation.pdf\&ei=mOkqVIWfG YKE7gbD8YH4Dg\&usg=AFQjCNE3AJi8kvmHHokQUZZI7JgjILnAsw\&bvm=bv . 76477589 ,d.cWc>.

Yusuf, F., and J. Iwu. "Use of Academic Library: A Case Study of Covenant University, Nigeria." Chinese Librarianship: An International Electronic Journal 30 (2010): 1-12. Web. 10 Feb. 2014. <http://www.iclc.us/cliej/cl30YI.pdf>. 